\title{
Declines in the energy content of yearling non-native alewife associated with lower food web changes in Lake Michigan
}

\author{
S. A. POTHOVEN \\ National Oceanic and Atmospheric Administration, Great Lakes Environmental Research Laboratory, Muskegon, MI, USA
}

\section{G. L. FAHNENSTIEL}

Great Lakes Research Center and Michigan Tech Research Institute, Michigan Technological University, Houghton, MI, USA

and Water Center, University of Michigan, Ann Arbor, MI, USA

\begin{abstract}
Juveniles of non-native alewife, Alosa pseudoharengus (Wilson), were collected in Lake Michigan in 1998, 1999, 2010, 2011 and 2013 to evaluate changes in energy content during a period of major ecosystem changes. Consistent with historical data, energy content of yearling alewife declined from late winter into late spring and was at its lowest point in June. Energy density and length-adjusted, entire-body energy were lower in 2010,2011 and 2013 than in 1998 and 1999. Energy losses over the first winter in the lake were more severe for the 2010 year class (56\% decrease) than for the 1998 year class (28\% decrease). Alewife diets in late spring of 2010-2013 reflected the loss of major prey such as Diporeia spp. and a shift towards lower energy prey. The recent decline in energy content of yearling alewife can be linked to recent changes in productivity and abundance of key components of the lower food web of Lake Michigan following the dreissenid invasion.
\end{abstract}

K E Y W O R D S : $\quad$ Alosa, Diporeia, Dreissena, energy density, overwinter, trophic level.

\section{Introduction}

Knowledge about the energy content of fish is important to understand the relationship between fish and their prey. Decreases in energy density of fish have been associated with both altered feeding rates and changes in the energy content of their prey (Madenjian et al. 2000, 2006; Pothoven et al. 2011). Energy content is often associated with the health of fish (Rottiers \& Tucker 1982; Madenjian et al. 2000), and it is particularly important for fish to have adequate energy reserves during the winter - a period of reduced growth and food availability, as seen for example in yellow perch, Perca flavescens (Mitchill) (Post \& Evans 1989), Atlantic silversides, Menidia menidia L. (Schultz \& Conover 1997), striped bass, Morone saxatilis (Walbaum) (Hurst \& Conover 2003) and lake herring, Coregonus artedi (Lesueur) (Pangle et al. 2004). Inadequate energy stores are thought to contribute to higher overwinter mortality directly through starvation or by enhancing vulnerability to predation (Garvey et al. 2004;
Pangle et al. 2004; Hurst 2007) or stressful thermal conditions (Bergstedt \& O'Gorman 1989). To ensure adequate energy stores are available for overwinter, many fish have adapted seasonal patterns that favour allocating energy towards storage prior to winter, with larger fish having more capacity to store energy than smaller fish (Schultz \& Conover 1997; Hurst \& Conover 2003; Heermann et al. 2009).

The alewife, Alosa pseudoharengus (Wilson), a nonnative fish that is now the dominant planktivore and a key component of the ecosystem in Lake Michigan, is responsible for restructuring zooplankton (Wells 1970) and native planktivore populations (Bunnell et al. 2006; Madenjian et al. 2008). The alewife now also represents the primary forage fish of salmonines (Jacobs et al. 2013). Young alewife deplete a large amount of their body energy over their first winter in Lake Michigan, and age-0 alewife in an inundated river mouth of Lake Michigan did not shift towards energy storage in autumn, suggesting that young alewife might not have an optimal energy 
allocation strategy for survival in the Great Lakes (Höök \& Pothoven 2009). Overwinter mortality of alewife is thought to be more severe in populations with low energy reserves (Brown 1972; Flath \& Diana 1985; O'Gorman \& Schneider 1986; Bergstedt \& O'Gorman 1989), although the direct mechanisms are unclear (Lepak \& Kraft 2008; Snyder \& Murray 2009; Dunlop \& Riley 2013). Furthermore, mass mortalities of alewife (die-offs) frequently occur during late spring (Brown 1968 Brown 1972; Flath \& Diana 1985), so yearling alewife that survive their first winter into March-May might not necessarily survive until summer (Höök \& Pothoven 2009). One factor that could contribute to alewife die-offs in the spring is continued loss of energy by yearling alewife into June (Madenjian et al. 2006; Höök \& Pothoven 2009).

The Lake Michigan food web has been altered dramatically since the 1990 s, following the proliferation of dreissenid mussels and subsequent decline of the spring phytoplankton bloom (Fahnenstiel et al. 2010) and summer deep chlorophyll layer (Pothoven \& Fahnenstiel 2013). Other notable changes in the food web include the nearly complete disappearance of the amphipod Diporeia spp. (Nalepa et al. 2009), shifts in zooplankton assemblages (Vanderploeg et al. 2012), and declines in alewife abundance (Bunnell et al. 2006). The first objective for this study was to document seasonal patterns of energy content for yearling alewife during this period of ecosystem change. To accomplish this objective, alewife were collected in 1998, 1999, 2010, 2011 and 2013, with an emphasis on June, when energy content was expected to be at its lowest point (Madenjian et al. 2006; Höök \& Pothoven 2009). Energy content was expected to be lower in the later years owing to decreasing productivity in the lake (Fahnenstiel et al. 2010) and declines in major food groups following dreissenid invasions (Nalepa et al. 2009; Pothoven et al. 2010). Overwinter energy losses were also determined for two large year classes of alewife (1998 and 2010 year classes; C. Madenjian, U.S. Geological Survey, personal communication; Warner et al. 2013). Overwinter energy losses were expected to be more severe for the 2010 year class than for the 1998 year class related to declines in prey availability (Nalepa et al. 2009; Pothoven et al. 2010). Finally, interannual patterns in energy content between 19981999 and 2010-2013 were evaluated in the context of environmental factors, including prey availability, alewife diets and thermal regimes.

\section{Material and methods}

Alewife were collected as part of various projects in Lake Michigan along a $10-\mathrm{km}$ transect in water depths of $7-45 \mathrm{~m}$ in the vicinity of Muskegon, Michigan, USA. Fish were collected during the day using a 7.6-m skate bottom trawl with a 6.4-mm square-mesh cod liner. Alewife were collected during June in 1998, 1999, 2010, 2011 and 2013 to determine late spring energy content of yearling alewife (i.e. fish that had survived one winter). To determine overwinter energy losses during their first winter in the lake, alewife were collected in October 1998, June 1999 (1998 cohort), September 2010 and June 2011 (2010 cohort). To determine seasonal energy patterns for yearling alewife, alewife were collected in March, June, July, August, September and December 2010 and April, May, June, July and August 2013.

Upon capture, alewife were frozen in water to prevent freezer burn. After thawing, total length and weight of individual alewife were measured, and stomach contents were removed for diet analysis. A subsample of alewife specimens was selected for energy density analysis. Individual alewife were homogenised and dried to a constant weight for about three days at $70{ }^{\circ} \mathrm{C}$, and after drying, ground with a mortar and pestle. Entire homogenised fish (or a $1 \mathrm{~g}$ subsample for fish $>1 \mathrm{~g}$ dry weight) from each sampling were individually combusted in a Parr 1261 isoperibol calorimeter that had been standardised with benzoic acid. The mean $\mathrm{CV}$ for three replicate samples from an individual fish was determined to be $1.03 \%$ $(n=10)$, so only one sample was combusted for all subsequent fish. Mean CV for benzoic acid standardisations was $0.13 \%$. Each individual fish's proportional dry to wet weight, energy density (based on wet weight) and total body energy content $\left(\mathrm{J} \mathrm{g}^{-1}\right.$ wet weight $\times$ total wet weight) were determined.

Although individual young alewife were not aged, length-at-age information (e.g. Madenjian et al. 2003) and length-frequency distributions were used to classify individuals caught in June as age-1 (i.e. yearling) if their total length $\left(L_{\mathrm{T}}\right)$ was $\leq 120 \mathrm{~mm}$. Similarly, fish $\leq 110 \mathrm{~mm}$ in autumn were assumed to be age-0 fish, and nearly, all fish in that size group were $<100 \mathrm{~mm}$. While the 120 mm cut-off for June-caught age-1 alewife is fairly conservative, it is remotely feasible that some age-2 fish could be $<120 \mathrm{~mm}$. Nonetheless, this size range should largely encompass age- 1 fish.

To evaluate temporal patterns of energy dynamics, the allometric relationship (i.e. $E=\mathrm{a}_{\mathrm{T}}^{\mathrm{b}}$ ) between $L_{\mathrm{T}}$ (in $\mathrm{mm}$ ) and total body energy $(E)$ in $\mathrm{J}$ was used to compare energy across years or months. Length-specific total body energy content is a particularly useful index of condition because it encapsulates both length-specific tissue composition and weight (both of which influence condition). Previous studies indicate that both allometric slopes and constants provide insight into seasonal and 
ontogenetic patterns of energy allocation (e.g. Hurst \& Conover 2003).

A general linear model was used to evaluate the homogeneity of slopes relating $\log _{\mathrm{e}} E$ to $\log _{\mathrm{e}} L_{\mathrm{T}}$ by determining whether there was a significant interaction between the covariate $\left(\log _{\mathrm{e}} L_{\mathrm{T}}\right)$ and the factor (year or month). If slopes were homogenous, then an ANCOVA was used to compare mean energy content (adjusted to mean length) between years or months. Energy density ( $\mathrm{J} \mathrm{g}^{-1}$ wet weight) was compared among years or months using ANOVA followed by pairwise comparisons using a Tukey's HSD test. All statistical comparisons were performed using SYSTAT 11 (Systat Software Inc, San Jose CA, USA), with $P<0.05$ considered significant.

As part of a long-term NOAA research project in the area, water temperature was recorded at a 110-m deep site off Muskegon each month from March/April through November/December with a Sea-Bird CTD. Water temperature in March was used as an index of late winter temperature and in June as an index of late spring water temperature. Zooplankton abundance collected as part of the long-term NOAA research programme at a 45-m and a 110-m deep site off Muskegon was used an index of zooplankton prey abundance. Zooplankton was collected with entire water-column tows using a 0.5 -m-diameter, $153-\mu \mathrm{m}$ mesh net. Mean zooplankton abundance (i.e. copepods excluding nauplii + herbivorous cladocerans) was calculated from all tows from both sites across March-June as an index of late winter to early summer zooplankton availability for each year. Details on zooplankton collections and processing are available in Vanderploeg et al. (2012). Annual abundance of two other potential prey of alewife, Mysis diluviana (Loven) and Diporeia spp., was also available from the $45 \mathrm{~m}$ site off Muskegon. Mysis diluviana were collected at night with entire water-column tows using a 1-m-diameter, 1000- $\mu \mathrm{m}$ mesh net. Diporeia spp. were collected using a Ponar grab. Details on sampling for M. diluviana are available in Pothoven et al. (2010), and details on Diporeia spp. sampling are available in Nalepa et al. (2009). To evaluate which prey were eaten by alewife during June each year, stomachs were dissected, and prey were identified and measured. Published weight-length regressions were used to convert prey lengths to dry weights. Prey weights for each prey group were summed across all individual fish, and diet composition was determined as the percent of the total calculated dry weight for each year. Further details on diet analysis are available in Hondorp et al. (2005) and Pothoven and Vanderploeg (2004).

\section{Results}

In 2010, length-adjusted, entire-body energy of yearling alewife differed among months (ANCOVA; $F_{4,144}=15.82$,
$P<0.001)$ for March-September, with June having the lowest energy (Fig. 1a). In 2010, energy density was also lowest among months in June (Fig. 1c). In 2013, there was a significant interaction between the covariate $\left(L_{\mathrm{T}}\right)$ and the factor (month) confounding analysis of $L_{\mathrm{T}^{-}}$ adjusted, entire-body energy (Fig. 1b). However, an inspection of the regression lines indicated that energy was generally lowest in June or May for 2013. The May 2013 sampling took place on May 30, so it was essentially a June sample. Similarly, energy density of yearling alewife during April-August 2013 was lowest for fish collected in May-June, but remained low into July before increasing in August (Fig. 1d).

Length-adjusted, entire-body energy of yearling alewife in June differed among years (ANCOVA; $F_{4}$, $142=335, P<0.001)$, decreasing from a high in 1998 to its lowest point in 2013 (Fig. 2). Energy density of yearling alewife in June also differed significantly among years, with the highest values in 1998-1999 and the lowest values in 2010-2013 (Table 1).

The $L_{\mathrm{T}}$-adjusted, entire-body energy content of age-0 alewife declined overwinter between autumn (October or September) and June of the following year for both the 1998 (ANCOVA; $F_{1,24}=14.37, P<0.001$ ) and 2010 (ANCOvA; $F_{1,46}=51.11, P<0.001$ ) year classes (Fig. 3 ). However, the percent decline in energy content was more severe for the 2010 year class $(56 \%)$ than for the 1998 year class (28\%). Length-adjusted, entire-body energy content of age- 0 alewife in autumn did not differ between 1998 and 2010 (ANCOVA; $F_{1}, \quad 39=0.46$, $P=0.50)$, despite some variation between sampling date in autumn (19 October 1998 vs 20 September 2010). By contrast, energy content for these same cohorts of alewife the following June as yearlings (in 1999 and 2011) was lower for the 2010 year class than for the 1998 year class (ANCOVA; $F_{1,31}=9.1, P=0.005$ ). Although age-0 fish were collected in October in 1998 and September in 2010, this was probably not an important factor in the results because energy content did not differ for fish caught in September and December 2010 (ANCOVA; $F_{1}$, ${ }_{55}=1.6, P=0.21$ ).

The coldest water temperatures in late winter (March) and in late spring (June) at the $110 \mathrm{~m}$ site were in 2011 (Table 2). By contrast, the warmest late winter temperatures were found in 1998 and 2013, and the warmest late spring temperatures were in 1998 and 2010.

Spring (March-June) zooplankton densities were by far highest in 1998 (45 and $110 \mathrm{~m}$ sites combined) (Table 2). Zooplankton densities in 1999 were slightly higher than in 2010-2013. Copepods were the dominant zooplankton group each year $(>93 \%)$. Similar to zooplankton abundance, annual abundances of $M$. diluviana and Diporeia spp. were higher in 1998-1999 than in 

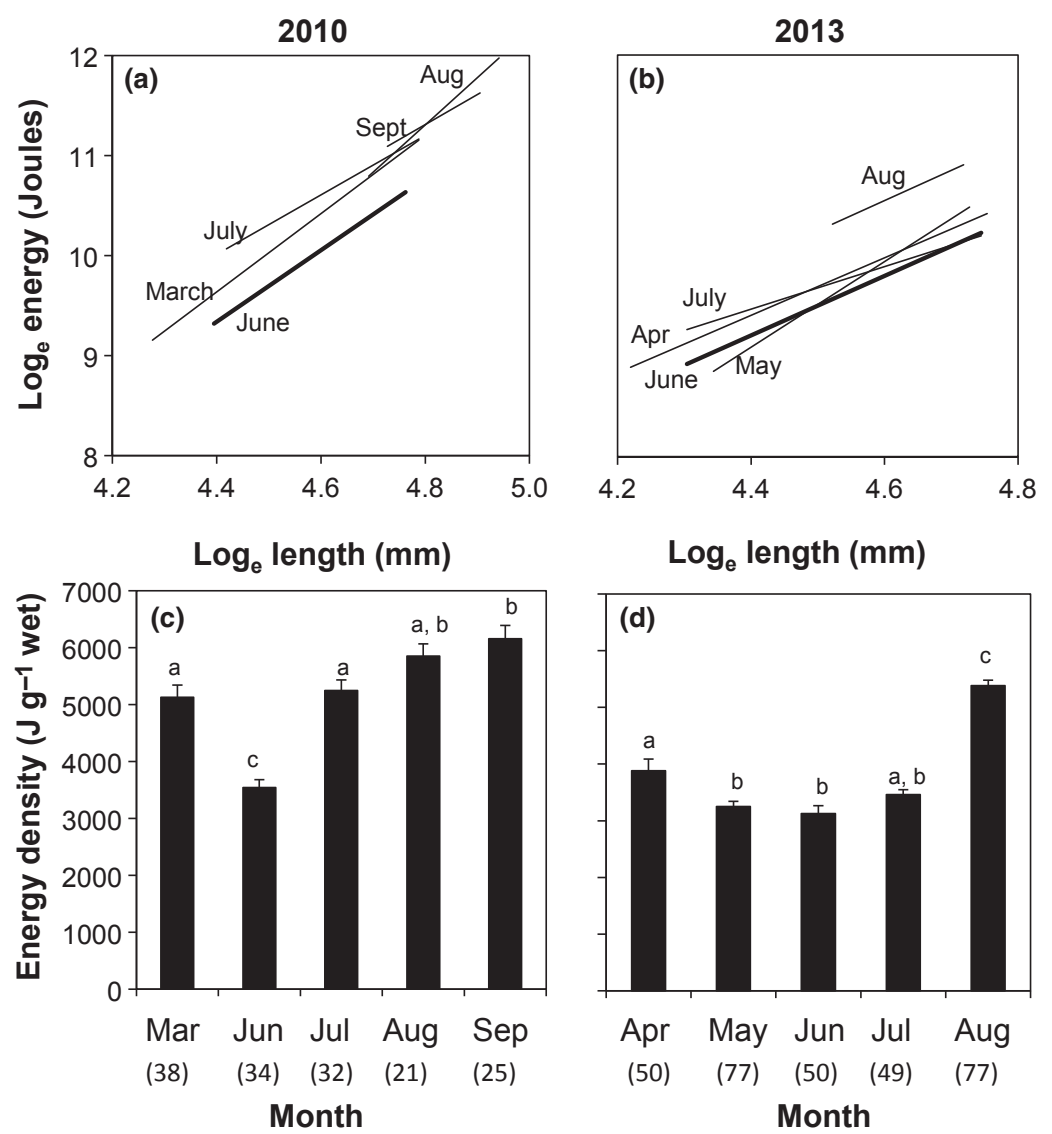

$\log _{e}$ length $(\mathrm{mm})$

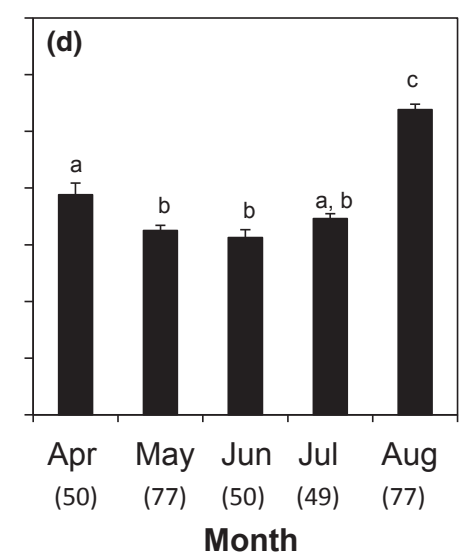

Figure 1. Energy content as a function of total length (a, b) and mean \pm SE energy density $(c, d)$ for yearling alewife from late winter to late summer in Lake Michigan in 2010 and 2013. For energy density, months within a year that share a common superscript letter were not significantly different (Turkey's HSD). Sample sizes for each month given in parentheses.

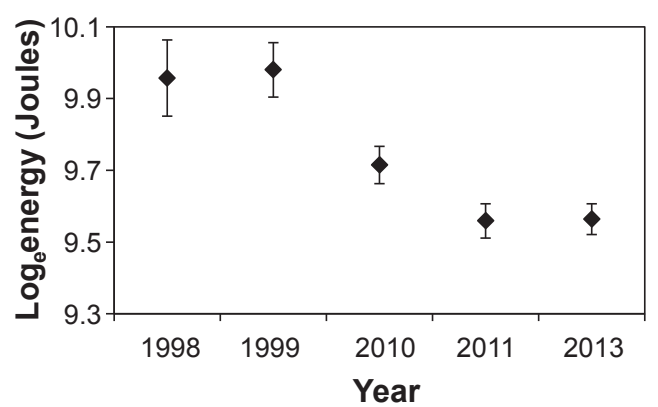

Figure 2. Mean $\pm \mathrm{SE} \log _{\mathrm{e}}$ energy adjusted to mean $\log _{\mathrm{e}}$ total length (i.e. $4.52 \mathrm{~mm}$ ) for yearling alewife in June 1998, 1999, 2010, 2011 and 2013.

2010-2013 (Table 2). Diporeia spp. were not found in the sampling region during 2010-2013.

The diet composition (\% dry weight) of yearling alewife in June exhibited notable variation among years (Fig. 4). Even with the interannual variation, large differences were noted between 1998-1999 and 2010-2013.
In 1998 and 1999, Diporeia spp. along with M. diluviana or copepods were the main components of the diet. By contrast, in 2010-2013, immature chironomids (larvae and pupae) along with copepods or small cladocerans, Bosmina longirostris (Müller), were the main prey eaten.

\section{Discussion}

Large differences in alewife condition were measured between the study periods of 1998-1999 and 2010 2013. These changes were reflective of more severe energy losses for fish over their first winter and lower post-winter energy content during June for yearling fish. Depleted energy reserves and poor condition have been associated with heightened overwinter mortality for fish (Pangle et al. 2004; Shoup \& Wahl 2011), including alewife (Brown 1972; Flath \& Diana 1985; O'Gorman et al. 1987). Although low energy reserves could directly lead to starvation (Adams et al. 1985; Hurst 2007), poor condition in fishes most likely combines 
Table 1. Mean \pm SE energy density $\left(\mathrm{J} \mathrm{g}^{-1}\right)$, dry:wet weight $(\%)$, total length $\left(L_{\mathrm{T}}, \mathrm{mm}\right)$, wet weight $(\mathrm{g})$, sample size (n), equation relating total energy (E, Joules) to $L_{\mathrm{T}}$ and $r^{2}$ of equation for alewife caught during June in 1998, 1999, 2010, 2011 and 2013

\begin{tabular}{llllllll}
\hline Year & Energy density & Dry:Wet & $L_{\mathrm{T}}$ & Weight & $n$ & Equation \\
\hline 1998 & $5523 \pm 528^{\mathrm{a}}$ & $25 \pm 1.4$ & $92 \pm 6$ & $4.8 \pm 1.2$ & 8 & $\ln \mathrm{E}=3.73 \times \ln L_{\mathrm{T}}-6.84$ \\
1999 & $4921 \pm 260^{\mathrm{a}}$ & $23 \pm 0.8$ & $87 \pm 4$ & $4.5 \pm 0.7$ & 16 & $\ln \mathrm{E}=3.70 \times \ln L_{\mathrm{T}}-6.67$ \\
2010 & $3544 \pm 137^{\mathrm{b}}$ & $17 \pm 0.4$ & $94 \pm 2$ & $5.7 \pm 0.3$ & 34 & $\ln \mathrm{E}=3.59 \times \ln L_{\mathrm{T}}-6.43$ \\
2011 & $3292 \pm 108^{\mathrm{b}}$ & $16 \pm 0.4$ & $96 \pm 2$ & $5.8 \pm 0.4$ & 40 & $\ln \mathrm{E}=3.84 \times \ln L_{\mathrm{T}}-7.75$ & 0.57 \\
2013 & $3128 \pm 139^{\mathrm{b}}$ & $15 \pm 0.4$ & $90 \pm 2$ & $4.7 \pm 0.3$ & 50 & $\ln \mathrm{E}=2.97 \times \ln L_{\mathrm{T}}-3.85$ & 0.51 \\
\hline
\end{tabular}

Energy density values that share a common superscript letter were not significantly different between years (Turkey's HSD).



Figure 3. Mean $\pm \mathrm{SE} \log _{\mathrm{e}}$ energy adjusted to mean $\log _{\mathrm{e}}$ total length (i.e. $4.34 \mathrm{~mm}$ for 1998 year class, $4.45 \mathrm{~mm}$ for 2010 year class) for alewife from the (a) 1998 and (b) 2010 year classes in the fall and the following June.

Table 2. Water temperature (in ${ }^{\circ} \mathrm{C}$ ) at a 110 -m site offshore of Muskegon during late winter (March) and late spring (June), mean crustacean zooplankton density (number $\mathrm{m}^{-3}$ ) from $45-\mathrm{m}$ and $110-\mathrm{m}$ sites offshore of Muskegon during March-June, and mean annual density of Mysis diluviana and Diporeia spp. (number $\mathrm{m}^{-2}$ ) at a $45 \mathrm{~m}$ site offshore of Muskegon

\begin{tabular}{llccrc}
\hline Year & March Temp. & June Temp. & Zooplankton & Mysis & Diporeia \\
\hline 1998 & 3.1 & 18.0 & 14421 & 123 & 5569 \\
1999 & 2.0 & 10.8 & 6499 & 40 & 1423 \\
2010 & 1.8 & 16.2 & 4612 & 14 & 0 \\
2011 & 1.0 & 6.5 & 3917 & 21 & 0 \\
2013 & 3.1 & 11.8 & 5312 & 9 & 0 \\
\hline
\end{tabular}

with other factors that result in death, such as increased susceptibility to thermal stress (Bergstedt \& O'Gorman 1989; Hurst 2007) or increased vulnerability to predation (McCollum et al. 2003; Garvey et al. 2004).

Overwinter energy losses for two relatively large year classes of alewife, the 1998 year class and the 2010 year class, were observed in this study. Based on these data, overwinter energy losses were considerably more severe for the 2010 year class than for the 1998 year class, even though energy content of age-0 fish did not differ

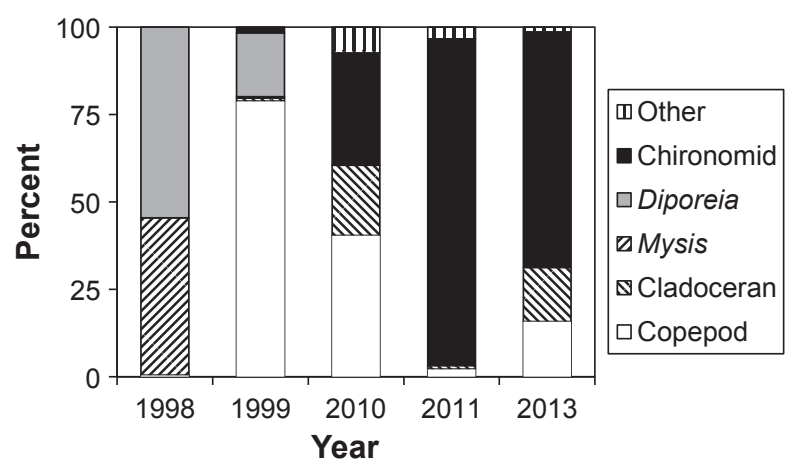

Figure 4. Diet composition (percent of total dry weight) for yearling alewife collected in June each year.

between these two year classes in autumn, indicating that the change in energy loss was due to factors between the autumn and June the following year. Overwinter energy losses are a well-documented occurrence for fish (Schultz \& Conover 1997; Hurst \& Conover 2003), including alewife (Flath \& Diana 1985; Höök \& Pothoven 2009), due to factors such as scarcity of resources and low feeding rates.

The lower energy content in June in 2010-2013 provides further support that overwinter energy declines have become more severe and yearling alewife are entering summer in poorer condition than in the late 1990s. Previous data indicated that energy depletion for small alewife continues into the early summer, reaching a low point around June (Madenjian et al. 2006; Höök \& Pothoven 2009). This study confirmed that yearling alewife still continue to lose energy through the spring into June. Furthermore, the yearling alewife from the 2012 year class demonstrated relatively low energy content over the entire late May to mid-July 2013 period before increasing in August. The continued depletion of energy into the early summer is consistent with observations from the 1960s that found that alewife that had survived the winter into April did not necessarily survive into the summer (Brown 1972). 
The recent decline in energy content of yearling alewife can be linked to recent changes in productivity and abundance of key components of the lower food web of Lake Michigan. Large decreases in primary productivity and phytoplankton abundance (Fahnenstiel et al. 2010), zooplankton abundance (Vanderploeg et al. 2012), the spring diatom bloom (Fahnenstiel et al. 2010), deep chlorophyll maximum (Pothoven \& Fahnenstiel 2013), Diporeia spp. abundance (Nalepa et al. 2009) and M. diluviana abundance (Pothoven et al. 2010) have been documented in Lake Michigan since the late 1990s. These have been attributed directly and indirectly to the colonisation of the lake by dreissenid mussels. Energy content of fish is driven primarily by feeding rate and food quality (Madenjian et al. 2000). A decline in specific consumption ( $g$ food $g$ fish ${ }^{-1} \mathrm{~d}^{-1}$ ) and the proportion of maximum consumption for alewife in Lake Michigan after the dreissenid invasion (Pothoven \& Madenjian 2008) indicate that alewife feeding rate has declined, which is consistent with declines in most major food types of young alewife (i.e. Diporeia, Mysis and zooplankton).

A major shift in the diet of young alewife observed in the current study reflects changes in abundance of key prey items in Lake Michigan. Diet composition of yearling alewife in June reflected the nearly complete loss of Diporeia spp. (see Nalepa et al. 2009) and declines of M. diluviana (Pothoven et al. 2010) in Lake Michigan, indicating that changes in food quality have taken place since 1998 as well. Most notably, the diet shifted from one that included energy-rich Diporeia spp. (4185 $\mathrm{J} \mathrm{g}^{-1}$ ) to a diet composed almost entirely of lower energy prey including chironomids (3185 $\mathrm{J} \mathrm{g}^{-1}$ ) and copepod zooplankton $\left(2300 \mathrm{~J} \mathrm{~g}^{-1}\right.$ ) (energy content values from Stewart \& Binkowski 1986; Lantry \& Stewart 1993). It is also possible that Diporeia spp. contained essential fatty acids that were important for overwinter survival of alewife (Kainz et al. 2010). Shifts in diet can also lead to situations where essential nutrients for overwinter survival are not obtained (Snyder \& Murray 2009). Although Diporeia spp. did not appear to be an important diet component for young alewife in some studies (Hewett \& Stewart 1989; Hondorp et al. 2005), data from Rand et al. (1995) and this study both indicated that Diporeia spp. were an important prey for small alewife, especially in the spring. The loss of Diporeia spp. from the environment and diets is consistent with lower energy content in late spring as this important prey is no longer available to alewife at a time when their energy reserves are low. Nalepa et al. (2009) indicated that the shift in the benthic community from one dominated by Diporeia spp. to one dominated by dreissenids represents a shift from a benthic community that provided an efficient pathway to higher trophic levels to one that represents an energy sink.

Changes in prey availability were not simply related to Diporeia spp. as declines in $M$. diluviana also appeared to have affected diet composition. Pothoven and Madenjian (2008) found that alternative energy-rich prey such as $M$. diluviana might not be available in sufficient quantities or densities to replace Diporeia spp. This appears to be the case, as M. diluviana declined in abundance in the environment and was absent from recent alewife diets. Another factor that could have contributed to decreased occurrence of $M$. diluviana in diets was that fewer alewife were collected at the deeper end of the sampling transect in 2010-2013 than in 19981999 (S. Pothoven, unpublished data). Although data on chironomid densities for the more recent years were not available, their densities are believed to have been relatively low for the duration of this study and largely unaffected by dreissenid mussels (T. Nalepa, University of Michigan, personal communication). Food web shifts, including loss of Diporeia and proliferation of Dreissena spp. in Lake Michigan, have been associated with declines in condition and energy content for other fish, including deepwater sculpin, Myoxocephalus thompsonii (Girard) (Hondorp et al. 2005; Pothoven et al. 2011), adult alewife (Hondorp et al. 2005; Madenjian et al. 2006) and lake whitefish, Coregonus clupeaformis (Mitchill) (Pothoven et al. 2001; Pothoven \& Madenjian 2008).

Other factors such as water temperatures and alewife abundance certainly affect feeding rates and therefore energy content. Abundance of yearling alewife likely varied among years owing to large differences in yearclass strength of age- 0 alewife the preceding autumn, that is the 1997 and 2009 year classes were considered poor, the 1998 and 2010 year classes were considered large, and 2012 year class was considered average (C. Madenjian, U.S. Geological Survey, personal communication; Warner et al. 2013). However, interannual differences in water temperatures or alewife abundance do not appear to be driving the dramatic declines in energy as much as food web changes. For example, energy content of yearling alewife in June 1998 and June 1999 was similar, despite much warmer late winter and spring water temperatures in 1998 along with much lower yearling alewife abundance. Furthermore, a relatively small cohort of yearling alewife in 2010 had experienced a relatively warm spring, but had much lower energy than yearling alewife in either 1998 or 1999. Finally, despite the yearling alewife caught in June 2013 experiencing a relatively mild winter and being part of an average year class, energy content was similar to that of yearling alewife caught in June 2011, which were part of a large 
year class that had experienced harsh overwinter conditions and a much colder spring.

The dramatic declines in yearling alewife energy content have implications for the management of the Lake Michigan and other systems impacted by dreissenid invasions. Sport fishing is a multibillion dollar industry in the Great Lakes, and a large component of the fishery is based on stocked Pacific salmonines that rely heavily on alewife as forage (Jacobs et al. 2013). Young alewife (this study) and older alewife (Madenjian et al. 2006) have lower energy in the post-dreissenid Lake Michigan environment. Alewife populations in poor condition are now potentially more vulnerable to severe conditions (Hurst 2007), which provides additional uncertainly into management strategies. Furthermore, evidence from Lake Huron, which suffered a catastrophic decline of alewife in 2003 due to a number of factors, suggests that poor food web conditions will decrease the resiliency of alewife populations after populations' declines (Dunlop \& Riley 2013).

Decreases in adult alewife energy density in Lake Michigan have led to increased consumption demands by Chinook salmon, Oncorhynchus tshawytscha (Walbaum), which need to eat more alewife to maintain growth rates and ration (Madenjian et al. 2006). Despite population declines, the importance of alewife in Chinook salmon diets has actually increased with small alewife accounting for a larger percentage of the diet and being consumed by a higher proportion of salmon (Jacobs et al. 2013). If low numbers of alewife prevent salmon from compensating for lower prey energy content, then they will experience lower growth, condition and possibly have higher incidences of disease (Rand et al. 1994). Late spring/early summer is a period of rapid growth for salmon (Stewart \& Ibarra 1991) and coincides with the timing of the lowest energy content for yearling alewife, placing additional pressures on alewife populations and providing salmon with foraging challenges to meet consumptive demands with alewife populations at historic low levels. Thus, ongoing lower food web changes present continued challenges to managers of forage fish and stocked salmonines in the Great Lakes and other dreissenid invaded systems.

\section{Acknowledgments}

We would like to thank all those who provided assistance in the field and laboratory, especially the crews of the RV Shenehon and RV Laurentian, D. Hondorp, D. Ruberg, A. Dunnuck and J. Elliott. Research was approved under GLERL animal care guidelines. GLERL-NOAA contribution 1726 and GLRC-MTU contribution 14.

\section{References}

Adams S.M., Breck J.E. \& McLean R.B. (1985) Cumulative stress-induced mortality of gizzard shad in a southeastern U.S. reservoir. Environmental Biology of Fishes 13, 103112.

Bergstedt R.A. \& O'Gorman R. (1989) Distribution of alewives in southeastern Lake Ontario in autumn and winter: a clue to winter mortalities. Transactions of the American Fisheries Society 118, 687-692.

Brown E.H. (1968) Population Characteristics and Physical Condition of Alewives, Alosa pseudoharengus, in a Massive Dieoff in Lake Michigan, 1967. Organisation Series Technical Report 13. Ann Arbor: Great Lakes Fisheries Commission, 20 pp.

Brown E.H. (1972) Population biology of alewives, Alosa pseudoharengus, in Lake Michigan, 1949-70. Journal of the Fisheries Research Board of Canada 29, 477-500.

Bunnell D.B., Madenjian C.P. \& Claramunt R.M. (2006) Longterm changes of the Lake Michigan fish community following the reduction of exotic alewife (Alosa pseudoharengus). Canadian Journal of Fisheries and Aquatic Sciences 63, 2434-2446.

Dunlop E.S. \& Riley S.C. (2013) The contribution of cold winter temperatures to the 2003 alewife population collapse in Lake Huron. Journal of Great Lakes Research 39, 682-689.

Fahnenstiel G.L., Pothoven S.A., Vanderploeg H.A., Klarer D., Nalepa T.F. \& Scavia D. (2010) Recent changes in primary production and phytoplankton in the offshore region of southeastern Lake Michigan. Journal of Great Lakes Research 36(Suppl. 3), 20-29.

Flath L.E. \& Diana J.S. (1985) Seasonal energy dynamics of the alewife in southeastern Lake Michigan. Transactions of the American Fisheries Society 114, 328-337.

Garvey J.E., Ostrand K.G. \& Wahl D.H. (2004) Energetics, predation, and ration affect size-dependent growth and mortality of fish during winter. Ecology 85, 2860-2871.

Heermann L., Eriksson L.-O., Magnhagen C. \& Borcherding J. (2009) Size-dependent energy storage and winter mortality of perch. Ecology of Freshwater Fish 18, 560-571.

Hewett S.W. \& Stewart D.J. (1989) Zooplanktivory by alewives in Lake Michigan: ontogenetic, seasonal and historical patterns. Transactions of the American Fisheries Society 118, 581-596.

Hondorp D.W., Pothoven S.A. \& Brandt S.B. (2005) Influence of Diporeia density on diet composition, relative abundance, and energy density of planktivorous fishes in southeast Lake Michigan. Transactions of the American Fisheries Society 134, 588-601.

Höök T.O. \& Pothoven S.A. (2009) Energy content of young alewives in eastern Lake Michigan and Muskegon Lake, a connected drowned river mouth lake. North American Journal of Fisheries Management 29, 378-387.

Hurst T.P. (2007) Causes and consequences of winter mortality in fishes. Journal of Fish Biology 71, 315-345. 
Hurst T.P. \& Conover D.O. (2003) Seasonal and interannual variation in the allometry of energy allocation in juvenile striped bass. Ecology 84, 3360-3369.

Jacobs G.R., Madenjian C.P., Bunnell D.B., Warner D.M. \& Claramunt R.M. (2013) Chinook salmon foraging patterns in a changing Lake Michigan. Transactions of the American Fisheries Society 142, 362-372.

Kainz M.J., Johannsson O.E. \& Arts M.T. (2010) Diet effects on lipid composition, somatic growth potential, and survival of the benthic amphipod Diporeia spp. Journal of Great Lakes Research 36, 351-356.

Lantry B.F. \& Stewart D.J. (1993) Ecological energetics of rainbow smelt in the Laurentian Great Lakes: an interlake comparison. Transactions of the American Fisheries Society 122, 951-976.

Lepak J.M. \& Kraft C.E. (2008) Alewife mortality, condition, and immune response to prolonged cold temperatures. Journal of Great Lakes Research 34, 134-142.

Madenjian C.P., Elliot R.F., DeSorcie T.J., Stedman R.M., O'Connor D.V. \& Rottiers D.V. (2000) Lipid concentrations in Lake Michigan fishes: seasonal, spatial, ontogenetic, and long-term trends. Journal of Great Lakes Research 26, 427444.

Madenjian C.P., Holuszko J.D. \& DeSorcie T.J. (2003) Growth and condition of alewives in Lake Michigan, 1984-2001. Transactions of the American Fisheries Society 132, 1104 1116.

Madenjian C.P., Pothoven S.A., Dettmers J.M. \& Holuszko J.D. (2006) Changes in seasonal energy dynamics of alewife (Alosa pseudoharengus) in Lake Michigan after invasion of dreissenid mussels. Canadian Journal of Fisheries and Aquatic Sciences 63, 891-902.

Madenjian C.P., O’Gorman R., Bunnell D.B., Argyle R.L., Roseman E.F., Warner D.M. et al. (2008) Adverse effects of alewives on Laurentian Great Lakes fish communities. North American Journal of Fisheries Management 28, 263-282.

McCollum A.B., Bunnell D.B. \& Stein R.A. (2003) Cold, northern winters: the importance of temperature to overwinter mortality of age-0 white crappies. Transactions of the American Fisheries Society 132, 977-987.

Nalepa T.F., Fanslow D.L. \& Lang G.A. (2009) Transformation of the offshore benthic community in Lake Michigan: recent shift from the native amphipod Diporeia spp. to the invasive mussel Dreissena rostriformis bugensis. Freshwater Biology 54, 466-479.

O'Gorman R. \& Schneider C.P. (1986) Dynamics of alewives in Lake Ontario following a mass mortality. Transactions of the American Fisheries Society 115, 1-14.

O’Gorman R., Bergstedt R.A. \& Eckert T.H. (1987) Prey fish dynamics and salmonine predator growth in Lake Ontario, 1978-84. Canadian Journal of Fisheries and Aquatic Sciences 44(Suppl. 2), 390-403.

Pangle K.L., Sutton T.M., Kinnunen R.E. \& Hoff M.H. (2004) Overwinter survival of juvenile lake herring in relation to body size, physiological condition, energy stores, and food ration. Transactions of the American Fisheries Society 133, 1235-1246.

Post J.R. \& Evans D.O. (1989) Size-dependent overwinter mortality of young-of-the-year yellow perch (Perca flavescens): laboratory, in situ enclosure, and field experiments. Canadian Journal of Fisheries and Aquatic Sciences 46, 1958-1968.

Pothoven S.A. \& Fahnenstiel G.L. (2013) Recent changes in summer chlorophyll $a$ dynamics of southeastern Lake Michigan. Journal of Great Lakes Research 39, 287-294.

Pothoven S.A. \& Madenjian C.P. (2008) Changes in consumption by alewives and lake whitefish after dreissenid mussel invasion in Lakes Michigan and Huron. North American Journal of Fisheries Management 28, 308-320.

Pothoven S.A. \& Vanderploeg H.A. (2004) Diet and prey selection of alewives in Lake Michigan: seasonal, depth, and interannual patterns. Transactions of the American Fisheries Society 133, 1068-1077.

Pothoven S.A., Nalepa T.F., Schneeberger P.J. \& Brandt S.B. (2001) Changes in diet and body condition of lake whitefish in southern Lake Michigan associated with changes in benthos. North American Journal of Fisheries Management 21, 876-883.

Pothoven S.A., Fahnenstiel G.L. \& Vanderploeg H.A. (2010) Temporal trends in Mysis relicta abundance, production, and life-history characteristics in southeastern Lake Michigan. Journal of Great Lakes Research 36(Suppl. 3), 60-64.

Pothoven S.A., Hondorp D.W. \& Nalepa T.F. (2011) Declines in deepwater sculpin Myoxocephalus thompsonii energy density associated with the disappearance of Diporeia spp. in lakes Huron and Michigan. Ecology of Freshwater Fish 20, 14-22.

Rand P.S., Lantry B.F., O'Gorman R., Owens R.W. \& Stewart D.J. (1994) Energy density and size of pelagic prey fishes in Lake Ontario, 1978-1990: implications for salmonine energetics. Transactions of the American Fisheries Society 123, 519-534.

Rand P.S., Stewart D.J., Lantry B.F., Rudstam L.G., Johannsson O.E., Goyke A.P. et al. (1995) Effect of lakewide planktivory by the pelagic prey fish community in Lakes Michigan and Ontario. Canadian Journal of Fisheries and Aquatic Sciences 52, 1546-1563.

Rottiers D.V. \& Tucker R.M. (1982) Proximate Composition and Caloric Content of Eight Lake Michigan Fishes. Federal Government Series - Technical Report 108. Ann Arbor: United States Fish and Wildlife Service, 8 pp.

Schultz E.T. \& Conover D.O. (1997) Latitudinal differences in somatic energy storage: adaptive responses to seasonality in an estuarine fish (Atherinidae: Menidia menidia). Oecologia 109, 516-529.

Shoup D.E. \& Wahl D.H. (2011) Body size, food, and temperature affect overwinter survival of age-0 bluegills. Transactions of the American Fisheries Society 140, 12981304.

Snyder R.J. \& Murray E.K. (2009) Influence of dietary nutrients on low temperature tolerance of freshwater alewives. Journal of Great Lakes Research 35, 473-476. 
Stewart D.J. \& Binkowski F.P. (1986) Dynamics of consumption and food conversion by Lake Michigan alewives: an energetics-modeling synthesis. Transactions of the American Fisheries Society 115, 643-661.

Stewart D.J. \& Ibarra M. (1991) Predation and production by salmonine fishes in Lake Michigan, 1978-88. Canadian Journal of Fisheries and Aquatic Sciences 48, 909-922.

Vanderploeg H.A., Pothoven S.A., Fahnenstiel G., Cavaletto J.F., Liebig J.R., Stow C.A. et al. (2012) Seasonal zooplankton dynamics in Lake Michigan: disentangling impacts of resource limitation, ecosystem engineering, and predation during a critical ecosystem transition. Journal of Great Lakes Research 38, 336-352.

Warner D.M., O’Brien T.P., Farha S.A., Claramunt R.M. \& Hanson D. (2013) Status of Pelagic Prey Fishes in Lake Michigan, 2012. Report to Great Lakes Fishery Commission Lake Michigan Committee Meeting, Duluth MN, March 19, 2013. Ann Arbor: U.S. Geological Service, 12 pp.

Wells L. (1970) Effects of alewife predation on zooplankton populations in Lake Michigan. Limnology and Oceanography 15, 556-565. 